\title{
THE TERRITORIAL EXPANSION OF VILNIUS: PLANS AND THEIR REALISATION (1916-1940)
}

\author{
Vitalija Stravinskiene
}

\begin{abstract}
The paper analyses the territorial expansion of Vilnius in the first half of the 20th century, based on archival and historiographic material. The 'grand' plan for Vilnius' expansion that the German government started realising during the years of the First World War continued into the 'Polish' (1919-1939) and 'Lithuanian'(1939-1940) stages of the city's development. The author concentrates not just on the government's decisions to geographically expand the city, but also on the ethnic demographic structure of the day, its changes, and how it related to the territorial expansion of Vilnius.
\end{abstract}

\section{Introduction}

Scientists from various fields have been interested in 20th-century Vilnius, ranging from historians, urban scientists and architects to art researchers, heritage protection specialists, and so on. There are a number of works bringing to light various issues regarding the historical development of Vilnius. Jurgis Vanagas and Ježis Survilo have discussed Antakalnis; Elmantas Meilus, Vytautas Jogèla, Virgilijus Pugačiauskas have discussed Lukiškès; Albertas Vitkus has discussed Verkiai; Rimgaudas Ryliškis has discussed Markučiai; Vytautas Lisauskas, Aušrelė Racevičienè and Jūratė Jurevičienè have discussed Užupis and Paplauja; Jerzy Szałygin, Maja Ptašek and Agnè Rymkevičiūtė have looked at Žverrynas; Stefan Rosiak and Teresa Klimašauskienè have discussed Pavilnis; and Viltė Janušauskaite has discussed Lazdynai. ${ }^{1}$ These authors' works contain general information

${ }^{1}$ J. Vanagas, Primirštas Antakalnis (Vilnius, 2015); J. Survilo, Pamiętam Antokol: przechadzki po Wilnie (Vilnius, 2005); E. Meilus, V. Jogėla, V. Pugačiauskas, Lukiškès: nuo priemiesčio iki centro (XV a. - XX a. pradžia) (Vilnius, 2008); A. Vitkus, Verkiai. Istorija ir dabartis (Vilnius, 2009); R. Ryliškis, Markučiai: Vilnios slènis (Vilnius, 2010); V. Lisauskas, Vilnius: Užupis ir gretimos erdvès (Vilnius, 2002); A. Racevičienè, Teritorija tarp Maironio, Aukštaičiu, Paupio, Zarasu ir Polocko gatviu. Istorinès urbanistinès raidos analizé (Vilnius, 2006); J. Jurevičienè, 'Medinè 
about the transformation of certain suburbs into part of the city, the decisions of the prevailing government of the day on the city's reorganisation, and so on.

Antanas Rimvydas Čaplinskas, Darius Pocevičius, Vladas Drèma, Vida Girininkienė, Audronè Kasperavičienė, Jerzy Surwiło, Vytautas Šiaudinis, Morta Baužienè and Tomas Venclova, ${ }^{2}$ among other authors, have written about streets and street names in 20th-century Vilnius, various objects (e.g. cemeteries, houses of prayer), and the history of some of the city's more prominent figures.

The works by Dalia Dijokienė and Jūratė Jurevičienè about Vilnius' historic suburbs and their development are noteworthy. ${ }^{3}$ The first author categorised suburbs in Vilnius according to: 1) those closer to the city's core (the area defined by the city wall [e.g. Užupis, Paplauja]), and 2) those further away (Žvèrynas, Žvejai, Antakalnis). ${ }^{4}$ With regard to the period the author researched (before 1939), another group of suburbs should be distinguished, those lying furthest away

architektūra istoriniame priemiestyje. Vilniaus Užupio autentiškumas', Urbanistika ir architektūra, 2002, t. XXVI, No. 1, pp. 11-17; J. Szałygin, 'Zabytkowa drewniana architektura mieszkalna wileńskiego Zwierzyńca’, Ochrona Zabytków, 2010, no 1-4, pp. 215-244; M. Ptašek, 'Žvėryno užstatymas ir pastatų stilistinè charakteristika', Vilniaus Technikos Universiteto mokslo darbai. Urbanistika ir rajonu planavimas, 1993, No. 18, pp. 85-103; A. Rymkevičiūtè, 'Medinis Vilniaus paveldas: Žvėryno medinès architektūros vertės', http://www.bernardinai.lt/straipsnis/-/3693 [accessed 10-02-2016]; S. Rosiak, Wileńska Kolonja Kolejowa, 1908-1933 (Wilno, 1933); T. Klimašauskienè, Pavilnys, 1908-2008: Wileńska Kolonja Kolejowa (Vilnius, 2008); V. Janušauskaitė, 'Lazdynai - sukonstruota vietos dvasia? ', Vietos dvasios beieškant, ed. R. Čepaitienè (Vilnius, 2014), pp. 392-422; Pasižvalgymai po Vilniu: miesto mikrorajonai (Vilnius, 2015); M. Jackiewicz, Wilno $w$ XX wieku. Ludzie $i$ wydarzenia (Bydgoszcz, 2013).

${ }^{2}$ R. A. Čaplinskas, Vilniaus gatvès. Istorija, vardynas, žemélapiai (Vilnius, 2010); R.A. Čaplinskas, ک̌v. Jono, Dominikonu, Traku gatves (Vilnius, 1998); R.A. Čaplinskas, Vilniaus istorija: legendos ir tikrové (Vilnius, 2010); D. Pocevičius, 100 istoriniu Vilniaus reliktu (Kaunas, 2016); V. Drèma, Dingęs Vilnius (Vilnius, 1991); V. Drema, Vilniaus namai archyvu fonduose (Vilnius, 1998) and his other works; V. Girininkienè, Vilniaus Bernardinu kapinès (Vilnius, 2010); V. Šiaudinis, Vilniaus maldos namai (Vilnius, 2001); A. Kasperavičienè, J. Surwiło, Przechadzki po Wilnie. Zarzecze. Cmentarz Bernardyński (Wilno, 1997); Vilnius: 100 memorable sites of Jewish history and culture (Vilnius, 2006); M. Baužienè, Pasižvalgymas anapus Vilniaus miesto gynybinès sienos (Vilnius, 2015); M. Baužienè, Pasižvalgymas po senojo Vilniaus mūrus (Vilnius, 2012); T. Venclova, Vilniaus vardai (Vilnius, 2006).

${ }^{3}$ D. Dijokiené, 'Vilniaus istorinių priemiesčių genezès, raidos ir vertybių ypatumai', Urbanistika ir architektūra, XXX, (2006), pp. 78-86; J. Jurevičienè, Vilniaus istoriniai priemiesčiai: autentiškumo aspektas. Daktaro disertacija (Vilnius, 2005).

${ }^{4}$ D. Dijokienè, Vilniaus, pp. 79, 83. 
from the city centre (Jeruzale, Liepkalnis, etc). Jurevičienè followed the same categorisation, but her field of research is wider, and spans areas such as Jeruzalè and Žemieji Paneriai. ${ }^{5}$

Indre Čiurlioniene $\dot{e}^{6}$ has written about the intended expansion of Vilnius in the 19th and 20th centuries. However, the particular period that is the focus of this research is mostly overlooked. Ciurlioniene only briefly mentions the 'grand' plan of Vilnius prepared by the Polish government in 1936-1939, which was developed during the years of the Second World War (1939-1943). ${ }^{7}$

Thus, the geographical expansion of Vilnius in the first half of the 20th century, especially during the 'Polish' stage of development (1919-1939), has not really received researchers' attention. Incidentally, information about certain plans for the city's development made by Polish government institutions can be found in the works of Abraham Mezelin, Adolf Richter, Witold Bańkowski, Rasa Antanavičiūte and Jūratė Markevičienè. ${ }^{8}$

Therefore, the preparation of this paper entailed finding primary sources, such as statistical yearbooks ${ }^{9}$ and census data from various periods, ${ }^{10}$ that contain information not just about demographic

5 J. Jurevičienè, Vilniaus, p. 9.

${ }^{6}$ I. Čiurlionienè, 'Vilniaus miesto planavimo raida: kai kurie estetinių aspektų ypatumai', http://leidykla.vgtu.lt/conferences/seselgio_2008/b.s/pdf/ciurlioniene_23-39.pdf, pp. 23-39 (accessed 25-04-2016).

${ }^{7}$ Ibid., pp. $30-31$.

${ }^{8}$ R. Antanavičiūtè, Politinès galios simboliai Vilniaus viešojoje erdvejje 1895 1953 metais. Daktaro disertacija (Vilnius, 2015); R. Antanavičiūtè, 'Viešosios Vilniaus erdvès tarpukariu: Antrosios Žečpospolitos didmiesčio konstravimas', Sostine kaip tapatumo simbolis. Vilnius ir Kaunas tarpukario kultūroje, ed A. Lapinskienè, V. Šeina (Vilnius, 2014), pp. 53-92; J. Markevičienè, 'Nuo šiuolaikinio miesto iki sostinès: urbanistinio Vilniaus ivvaizdžio kaita 1936-1939 m. ir 19391940 m.', Sostine kaip tapatumo simbolis. Vilnius ir Kaunas tarpukario kultūroje, ed A. Lapinskienè, V. Šeina (Vilnius, 2014), pp. 93-112; A. Mezelin, Przyczynek do znajomości struktury wiekowej Wilna (Kraków, 1936); A. Richter, 'Bezrobotny proletariat w Wilnie', Wilno, No. 2, (1939), pp. 155-163; W. Bańkowski, Wilno przyszłości. Rozważania na tematy urbanistyczne (Wilno, 1937).

${ }^{9}$ Rocznik Statystyczny Wilna 1921-1928 (Wilno, 1930); Rocznik Statystyczny Wilna 1931 (Wilno, 1933); Rocznik Statystyczny Wilna 1935 (Wilno, 1937); Rocznik Statystyczny Wilna 1936 (Wilno, 1938); Prace statystyczne zarzadu miejskiego $w$ Łodzi 1918-1934 (Łódź, 1937).

10 Первая всеобщая перепись населенія Россійской имперіи, 1897 г. IV. Виленская губернія, 1900, т. 1; Lietuvos gyventojai: pirmojo 1923 m. rugsejjo 17 d. visuotinio gyventojų surašymo duomenys, [1924]; Drugi powszechny spis ludności z dn. 9. XII. 1931 r: Mieszkania i gospodarstwa domowe. Ludność. 
indicators, but also about the territorial expansion of cities. These statistical collections were also useful in a comparative sense, as they allowed a comparison of the situation of Vilnius to other cities.

The main source was material from archives and manuscript departments. The documents found in the Lithuanian State Historical Archives Oberost Collection (641) allowed the reconstruction of the territorial reorganisation of Vilnius during the First World War. Material from the Lithuanian Central State Archives (LCVA) formed the basis for an analysis of administrative territorial changes in Vilnius when it was part of Poland, and then Lithuania. Based on the decisions, resolutions, orders, maps, city development plans and other documents of central and local government institutions found in this archive, the author aimed to determine the city's administrative boundaries, and trends in its development over a longer perspective. Documents from the Statistics Department of the Vilnius Magistrate are also worth mentioning. This department made a record of the quantitative changes to the city's population in separate parts of the city, its ethnic structure, etc. An analysis has allowed the determination of the distribution of population in the city, the population's ethnic structure, each ethnic group's association with separate parts of the city, and aspects thereof.

The first point selected for this research is the beginning of the territorial changes made to Vilnius by the German occupying government. The second is the sphere of activity of the administration of the Republic of Lithuania in expanding the capital's geographical space. Thus, the paper discusses the reorganisation by three governments (German, Polish and Lithuanian) in the first half of the 20th century.

The aim of this article is to examine the territorial expansion of the city of Vilnius in 1916-1940, revealing the existing government's resolutions on defining city boundaries, analysing the dynamics of the city's demographic situation, and the ethnic distribution of the population.

Several stages can be distinguished in Vilnius' development during the period researched: 1) the years of the First World War (1916), when the area of Vilnius almost doubled in size; 2) 1919 to 1939, the

Stosunki zawodowe: Miasto St. Warszawa (Warszawa, 1937); Drugi powszechny spis ludności z dn. 9. XII. 1931 r: Mieszkania i gospodarstwa domowe. Ludność. Stosunki zawodowe: Miasto Łódź (Warszawa, 1937); Drugi powszechny spis ludności z dn. 9. XII. 1931 r: Mieszkania i gospodarstwa domowe. Ludność. Stosunki zawodowe: Miasto Kraków (Warszawa, 1937). 
expansion of Vilnius' boundaries by Polish government institutions, their correction and the preparation of long-term development plans; and 3) 1939 and 1940, when Vilnius was integrated into the Republic of Lithuania, and the city's territorial development continued.

\section{The creation of 'greater' Vilnius}

Extensive territorial development of Vilnius took place in the 20th century. On the eve of the First World War (1913), it tripled in size (from 1,550 hectares to 5,000 hectares, according to some data, and even 5,400 hectares according to other data). ${ }^{11}$ The outbreak of war interrupted the city's territorial development, and in the autumn of 1915, the German occupying government started to revise the city's area. By the beginning of the following year (14 January 1916), it had considerably expanded Vilnius' boundaries. ${ }^{12}$ By this time, Vilnius (Stadtkreis Wilna) encompassed Antakalnis (Antokol), Baltupiai (Bołtupie), Burbiškès (Burbiszki), Dilgynè (Kropiwnica), Dilgynė (Podwysokie), Dubninkai (Dubniaki), Guriai (Góry), Guraičiai (Gurajcie), Justiniškès (Justynówka), Kaminai (Kominy), Kirtimai (Porubanek), Kloniai (Doly), Kryžiškès (Krzyżówka), Kuprijoniškès (Kuprjaniszki), Leoniškès (Leoniszki), Lyglaukiai (Rowne Pole), Lukiškès (Lukiszki), Markučiai (Markucie), Meškoniai (Mieszkańce), Naujakiemis (Nowosiołki), Naujamiestis (Nowy Gorod), Naujininkai (Nowy Świat), Naujieji Žuraičiai (Żurawice Nowe), Pakalniškès (Doliny), Pakupečiai (Podkopcowo), Paplauja (Poplawy), Pilimėliai (Pilimiele), Plytinè (Cegielnia), Rudaminos Kelias (Podkuprjaniszki), Ribiškès (Rybiszki), Riovonys (Rowiance), Šeškinè (Szyszkinie), Šnipiškès (Śnipiszki), Šveicarai (Szwajcary), Trinapolis (Trynapol), Tuputiškès (Topoczyszki), Užupis (Zarzecze), Vilkpèdè (Wilcza Łapa), Vingis (Zakret), Viršupis (Wierszuplia) and Žverrynas (Zwierzynec). ${ }^{13}$ Thus, visually speaking, the German government realised the 'greater' Vilnius plan. At this stage of the research, it is not known exactly when

${ }^{11}$ Data about the territorial area of Vilnius city from 1648 to 1934 from the Vilnius Magistrate's Technical Section, LCVA, f. 64, ap. 20, b. 777, 1. 4; 1936 Vilnius city investment programme, ibid., f. 64 , ap. 8, b. 361, 1. 220. Note that the area of the city indicated here was only approximate, as no actual measurements were made at the time.

12 Order of the army commander, 16 January 1916, LVIA, f. 641, ap. 1, b. $1059,1.8 \mathrm{~b}$.

${ }^{13}$ Alphabetisches Ortsverzeichnis des Verwaltungsbezirks Wilna-Suwalki (Wilna, 1916), pp. 4-58. 
the concept of 'greater' Vilnius came into use. What we do know is that some of the Vilnius intelligentsia at the time used the 'greater' Vilnius definition when speaking about the German occupying government's geographical expansion of the city. One such person was the cultural and scientific figure Michał Brensztejn, who entered 14 January 1916 in his journal as the date of the founding of 'greater' Vilnius'. ${ }^{14}$ The public in Vilnius were informed of the city's expansion on 6 August of the same year in the newspaper Wilnaer Zeitung. ${ }^{15}$

It should be noted that the German occupying government carried out similar territorial reorganisations in other cities as well, such as Warsaw and Łódź. One might ask why the Germans conducted this kind of expansion of cities, including Vilnius. No definitive answer exists, but it could be that purely pragmatic economic reasons were the basis. The more urban areas were separated from those that were strictly rural, and which promised greater revenue (through production). ${ }^{16}$ In addition, perhaps they thought that this reorganisation would offer greater resources to meet Germany's economic demands (an increase in the urban population would offer a greater pool of labour for work in Germany). ${ }^{17}$ (See Map No 1)

Another stage in the city's development started in 1919, when Lithuania and Poland were in a conflict over each state's respective territory. Once the Polish military became established in Vilnius, the Civil Administration of the Eastern Regions was formed, whose general commissioner, Jerzy Osmolowski, issued an order at the end of May over the marking of city boundaries for Vilnius. ${ }^{18}$ The order confirmed all the territorial changes in Vilnius that had been introduced by the German occupying government; it also foresaw that part of Verkiai (Werki) with an area of around 600 hectares would also be

14 Journal of M. Brensztejn, 14 January 1916, National Library of Poland, Special Collections, II.10610, t. 2, 1. 7.

15 'Der Stadtkreis Wilna', Wilnaer Zeitung, 196 (1916).

${ }^{16}$ B. Korzeniewski, 'Polityka ekonomiczna władz niemieckich okupacyjnych w czasie pierwszej wojny światowej i strategia przetrwania mieszkańców południowego Podlasia', Radzynski Rocznik Humanistyczny, 5 (2007), p. 42, http://www.rasil.home. pl/rrh_5_2007/04_boguslaw_korzeniewski.pdf (accessed 20-4-2016).

17 J. Snopko, 'Rządy niemieckie w Grodnie i okolicy (1915-1917)', Studia Podlaskie, XXII (2014), p. 172.

18 Order of the general commissioner of the Civil Administration of the Eastern Regions, 28 May 1919, LCVA, f. 64, ap. 8, b. 51, 1. 124. 


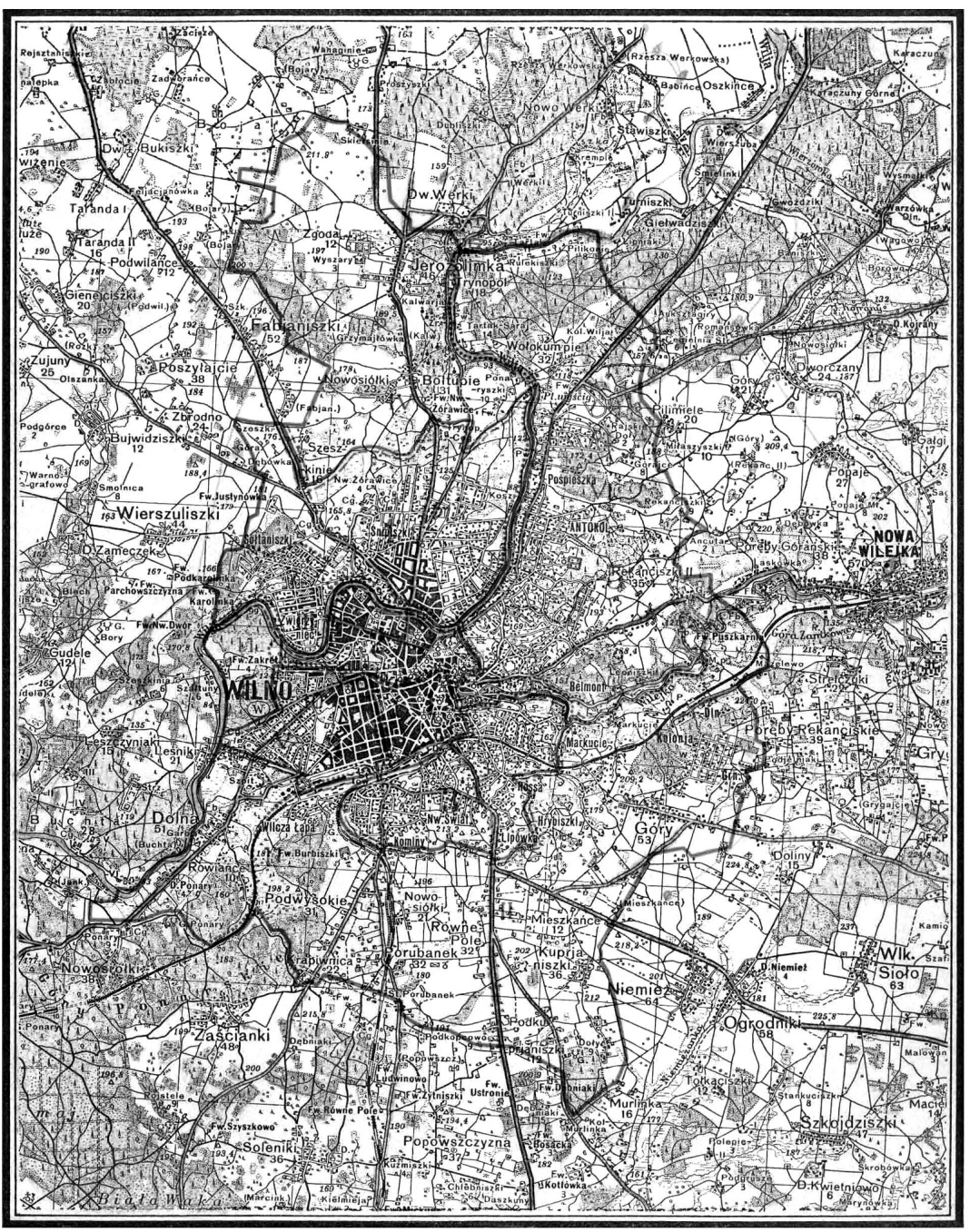

Map No 1. The area of 'greater' Vilnius

Source: Rocznik statystyczny Wilna 1935 (Wilno, 1937) 
incorporated into the city. ${ }^{19}$ Thus, the Polish government in effect continued the city's expansion begun by the Germans, and from then the area of Vilnius reached 10,400 hectares; later, the city boundaries remained basically the same (until 1939), with only minor corrections being made.

In the 1920s, according to its area, in all of Poland, Vilnius was surpassed only by Warsaw, which had an area of 12,100 hectares (Poznan was third, with 8,678.1 hectares). ${ }^{20}$ In those days, Vilnius was a 'spacious' city. In 1924, the built-up area covered 2,300 square kilometres, areas with no constructions 5,840 square kilometres, roads covered 420 square kilometres, parks, gardens and forests 60 square kilometres, bodies of water 40 square kilometres, and cemeteries 30 square kilometres. ${ }^{21}$ These are only approximate figures, as in reality, the city had not actually been measured then.

The definition of Vilnius' city boundaries was spurred on by the census planned for 1925 (although it never happened). It was noted that in some places, the city's area was not very clear, so a commission was formed to define its boundaries more precisely. It included Kazimierz Wimbor, the Polish government's delegate in Vilnius, Witold Bańkowski, the Vilnius city president, B. Grabowski, the Vilnius-Trakai district leader, Aleksander Reszczyński, the Vilnius city state police superintendent, and Frantiszek Walicki, the head of the City Measurement Section of the Vilnius City Magistrate. ${ }^{22}$ They reviewed the city's area from 26 to 30 October 1925, and defined the city's boundaries.

Later, more efforts were made to change the city's boundaries. In 1936, representatives of the Vilnius-Trakai district government appealed to the Vilnius Magistrate, requesting it to join part of the area of Vilnius city to the Riešè rural district (valsčius) (the suburbs of Jeruzale [Jerozolimka] and Baltupiai). After a discussion by the city council, the request was turned down. ${ }^{23}$

${ }^{19}$ Report on the area of Vilnius, its population, economic, legal and financial conditions in 1919-1929, ibid., ap. 20, b. 218, 1. 4.

${ }^{20}$ Ibid., 1. 3.

${ }^{21}$ Data about the area of Vilnius from 24 May 1924, ibid., ap. 8, b. 54, 1. 141v.

${ }^{22}$ Protocol from the meeting of the Vilnius Magistrate held on 31 October 1925, ibid., b. 90 , 1. 9.

${ }^{23}$ Note from H. Jensz, the head of the Vilnius Magistrate Technical Section, dated 25 July 1936, to the Vilnius-Trakai District municipal union, ibid., b. 375, 1. 2-2v. 


\section{The city centre of Vilnius and its suburbs}

The boundaries of the city of Vilnius gradually expanded as part of a long historical process. At the turn of the 18th and 19th centuries, Vilnius was surrounded by 13 suburbs; by the 1820 s there were ten suburbs; and in the late 19th century there were eight (Antakalnis, Paplauja and Užupis, Pohulanka, Lukiškès, Šnipiškès, Popinè, Naujamiestis, Naujininkai and Škaplerine, and Kaminai). ${ }^{24}$

During the First World War, the city was divided into the following zones: 1) the Old Town, 2) Naujininkai, Kaminai, Rasos (Rossa), Dunojus (Dunajka), 3) Lukiškès, 4) Šnipiškès, Tuskulènai (Tuskulanum), 5) Paplauja, 6) Popinè, Lyglaukiai, Belmontas (Belmont), 7) Antakalnis, 8) Naujamiestis, Paneriai, Vingis, and 9) Žvėrynas, Saltoniškès (Soltaniszki). Their boundaries are marked on the map. (See Map No 2).

Similar divisions remained later on. Lists of 'greater' Vilnius tell us that in the mid-1920s, Vilnius was identified as consisting of 96 villages, folwarks and suburbs. ${ }^{25}$ There were 19 suburbs: Antakalnis, Antakalnis forest, Eiguva (Derewnictwo), Dunojus, Liepkalnis (Lipówka), Miškiniai (Leśniki), Naujamiestis, Paneriai, Popinè, Paplauja, Pavilnys (Kolonia Kolejowa), Rasos, Rūdninkai (Rudnickie), Šnipiškès, Saltoniškès, šv. Stepono (Stefańskie), Trakų (Trockie), Žvejai (Rybaki), and Žverynas. Ten years later, the number reached 130, of which 38 were identified as district-suburbs (apart from those already mentioned, there was also Belmontas, Kloniai [beyond Kuprijoniškès], Geležinè trobelè [Żelazna Chatka], Ginklų aikštė [Plac Broni], Jeruzalè, Kaminai, Kirtimai, Markučiai, Pospieška [Pośpieszka], Sapiegos jurzdika [Juryzdyka Sapieżyńska], Škaplerinė [Szkaplerne], Šeškinè [Szeszkinie], Užkaminai [Zakominy], Vavozai [Wąwozy], Vilkpèdè, Vingis, Pakalniškès [Dolna/Doliny], Žemutiniai Žuraičiai [Żurowica Dolna] and the Aukštaičių Street district [Kopanica]). ${ }^{26}$ Some districts were 'reduced' (e.g. Sapiegu jurzdika was

${ }^{24}$ I. Janicka, Kultura higieniczna Wilna w latach 1795-1915 (Gdańsk, 2009), p. 101. M. Baliński, Opisanie statystyczne miasta Wilna (Wilno, 1835), p. 31. The author mentions Antakalnis, Popinè, Užupis, Paplauja, Rasos, Aštrųsis galas, Rūdninkai or Šv. Stepono, Pohulanka, Lukiškès and Šnipiškès; data from the 1897 census denoted these suburbs: Antakalnis, Belmontas, Užupis, Paplauja, Rasos, Šv. Stepono, Kaminai, Popinè, Šnipiškès, Lukiškès, Pohulanka, Naujamiestis, Vavozai, Liepkalnis, Первая всеобщая, p. 8.

${ }^{25}$ List of locations in greater Vilnius, LCVA, f. 64, b. 90, 1. 10-10v.

${ }^{26}$ List of locations in the city of Vilnius, ibid., b. $331,1.246-247 \mathrm{v}$. 


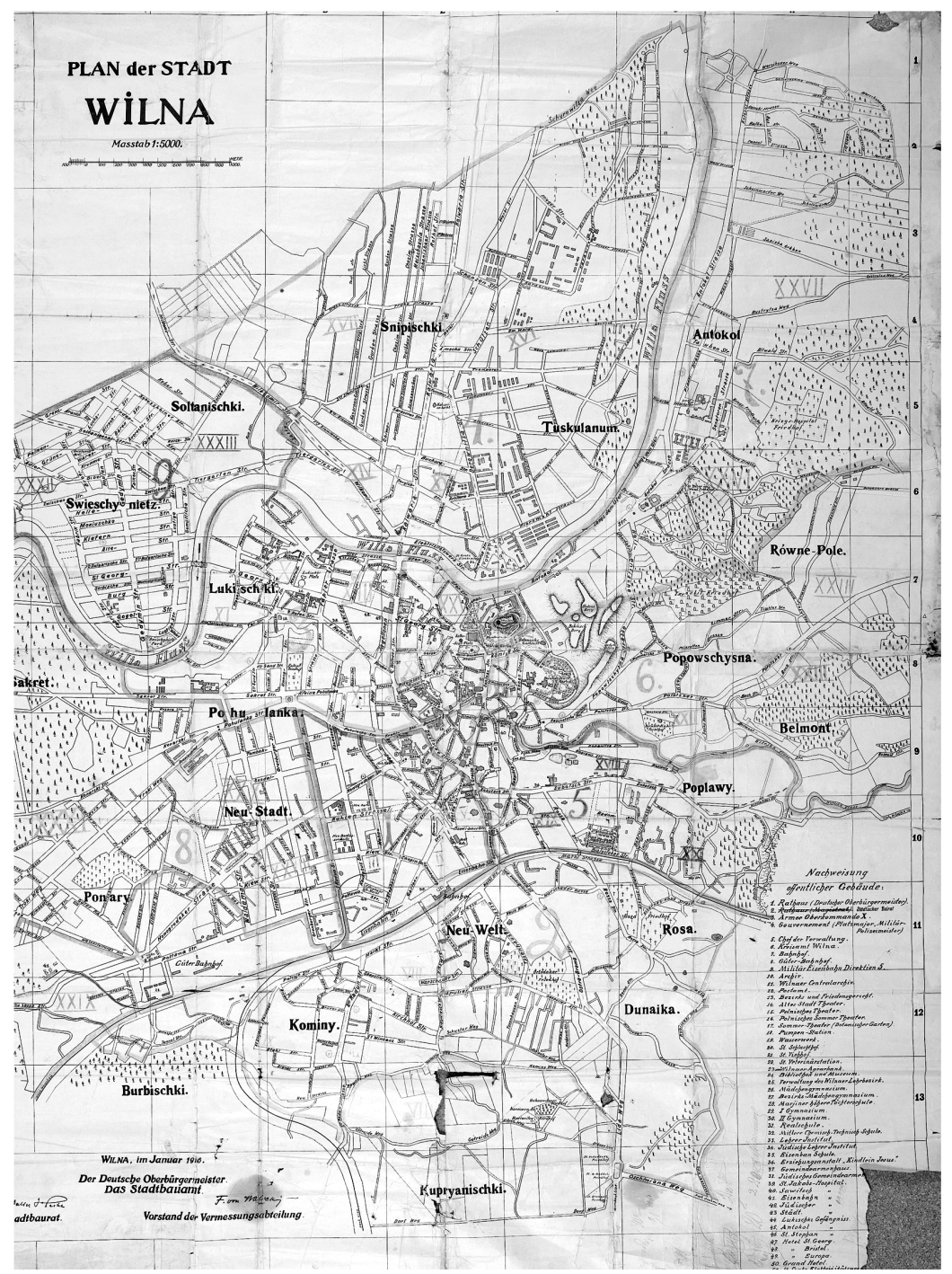

Map No. 2

Source: LCVA, f. 884, ap. 1, b. 228, 1. 1. 
set apart from the suburb of Antakalnis as a whole, as with Kopanica in Paplauja, and Dolna in Vilkpèdè). The city expanded mostly in easterly and westerly directions, as there were plans for a concentration of industrial and other large objects in these areas. For example, in the 1930s, plans were made to concentrate industrial companies in Paneriai, and the construction of an airport was due to commence in Kirtimai. ${ }^{27}$

The definition of a suburb (priemiestis) used in documents of the day during the period under analysis carried more of a historical meaning. A suburb identified an area that was in the middle of the city (Naujamiestis). At this time, places called suburbs were considered inseparable parts of the city, the people who lived there were considered residents the city, they paid city taxes, and their children attended the city's general education schools. For example, in the 1930s, there was the No. 34 seven-year school in Jeruzalè, the No. 23 four-class school in Pavilnys, and the No. 32 primary school in Kuprijoniškès. ${ }^{28}$ The same approach dominated in the establishment of various organisations. In 1927, under a decree from the Polish minister for religion and state education affairs, Jewish religious communities started to be founded. The Vilnius Jewish religious community consisted of all Jews who lived in 'greater' Vilnius. ${ }^{29}$

At the beginning of 1925, by order of the Polish government delegate in Vilnius, the city commissioner divided the city into two parts, the centre and the outskirts. ${ }^{30}$ The central part of the city consisted of the area visible on Map No. 3. The area beyond the marked boundary was considered the outskirts, a zone which incorporated locations that lay on the fringes of 'greater' Vilnius. (See Map No. 3).

\section{Plans for the development of Vilnius in the 1930s}

At the decision of the local Polish government, in the first half of the 1930s, the focus turned to plans for the development of Vilnius.

27 J. Kobzakowski, A. Wasilewski, 'O planie zabudowy Wilna, rozmowa urbanisty z laikiem', Wilno, No. 1 (1939), p. 41; decree from the Vilnius voivode dated 4 February 1938, LCVA, f. 130, ap. 1, b. 13222, 1. 7-7v.

${ }^{28}$ List of primary schools in the city of Vilnius (1930s), ibid., f. 172, ap. 1, b. $2608,1.8,10$.

2921 June 1927 'Decree from the Polish Minister for Religion and State Education Affairs', Dziennik Ustaw, No. 64, poz. 566, (1927), p. 847.

${ }^{30}$ Resolution of 31 March 1925 of the Vilnius city commissioner K. Wimbor, LCVA, f. 51, ap. 15, b. 607, 1. 10. 


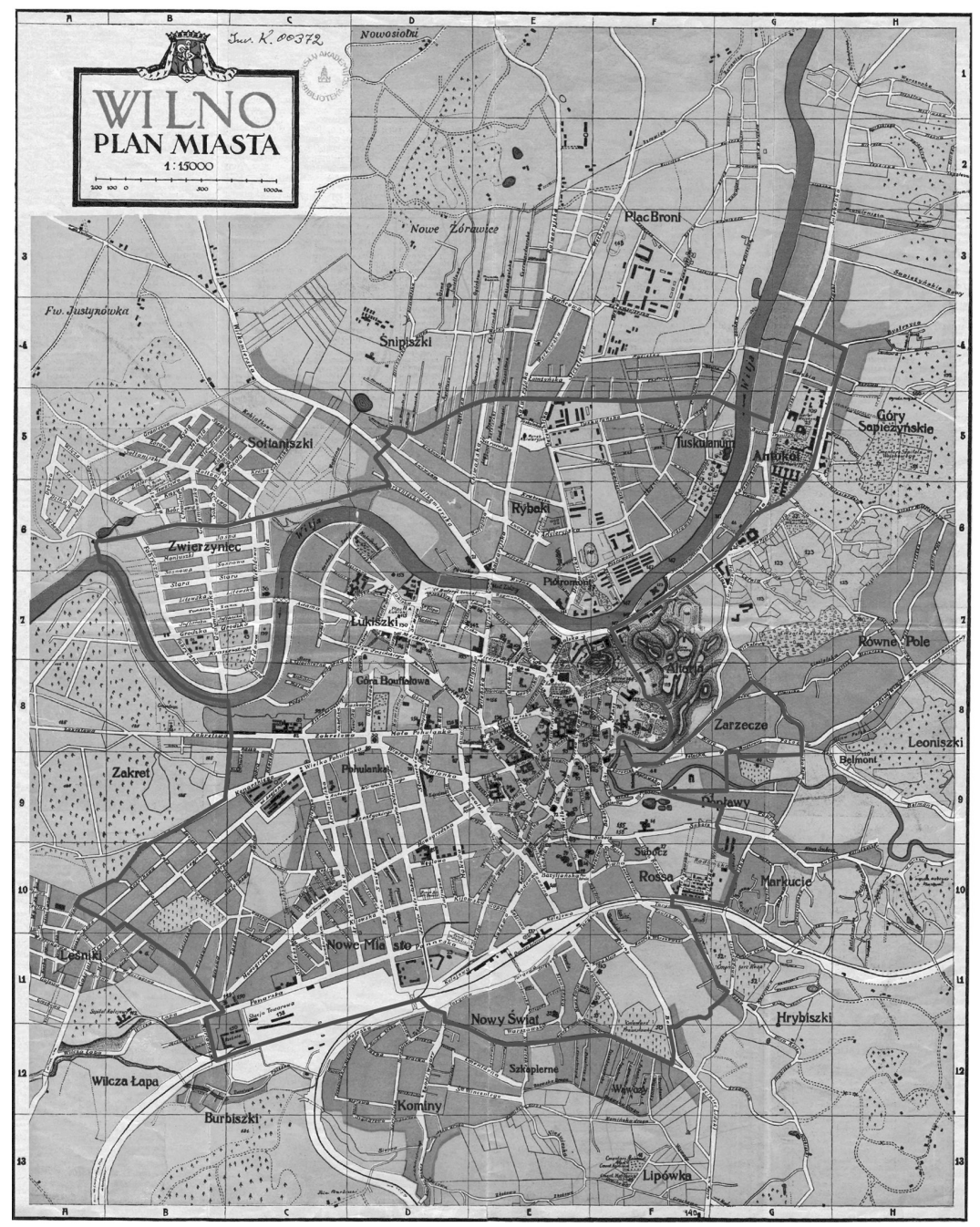

Map No. 3

Source: The Wroblewski Library Manuscript Department of the Lithuanian Academy of Sciences, K-508. Aira Dubikaltiene marked the city centre boundaries on the map. 
The Magistrate's Department of Measurement and Regulations was ordered to prepare a general plan for construction within the city. Its preparation gained momentum in 1933, when the Vilnius voivode instructed that the plan be made and presented for approval by the Ministry of Internal Affairs before 1 January $1936 .{ }^{31}$ The plan was necessary in order to properly plan the city's development, and the voivode's instructions were realised. It was presented to the public from 1 to 15 March 1936, and showed Vilnius as divided into three parts: 1) the Senamiestis (Old Town), 2) six zones where construction would be developed, and 3 ) areas not for construction. ${ }^{32}$ Construction was forbidden in the Senamiestis, while the construction of residential buildings and industrial objects was planned for other areas. Paneriai was set aside mostly for industry, for example. ${ }^{33}$ Most restrictions on construction applied to the central part of the city (where only fire retardant buildings 6.5 to eight metres in height could be built), while the restrictions became lighter further away from the centre (wooden buildings, one-storey buildings with attics, and so on, were permitted). ${ }^{34}$

The plan caused a stir among the city's population, as it foresaw greater landscaped areas and relaxation zones within the city. However, these zones encroached on some private land. No construction was permitted there, and the plots were to come under the city's jurisdiction. The affected members of the population complained to the City Magistrate, asking for changes to be made to the general plan. However, their requests were usually dismissed. The City Magistrate staff reverted to placing the city's interests above any private interests. ${ }^{35}$ In such cases, private owners were to receive compensation. The Vilnius voivode had to decide on the expropriation of plots of land and compensation. Based on his decree of 4 February 1938, compensation totalling 156,333. 97 zloty for over 38 hectares of land was foreseen

${ }^{31}$ Copy of the extract from the Vilnius voivode's note dated 19 April 1933, LCVA, f. 64, ap. 8, b. 361, 1. 77.

${ }^{32}$ Decree from the Polish minister for internal affairs on the Project for the Division of Greater Vilnius into Zones and Setting of Construction Site Sizes (1939), ibid., f. 64 , ap. 9, b. $8325,1.1$.

${ }^{33}$ J. Kobzakowski, A. Wasilewski, 'O planie zabudowy Wilna rozmowa urbanisty z laikiem', p. 41.

${ }^{34}$ Project for the Division of Greater Vilnius into Zones and Construction Site Sizes, LCVA, f. 51, ap. 10, b. 1219, 1. 2-8v.

${ }^{35}$ Decision from the Vilnius Magistrate's Technical Section (1939), ibid., f. 64, ap. 9 , b. $8325,1.25$. 
for private individuals and organisations whose property was expropriated for the construction of an airport. ${ }^{36}$ Bańkowski, the president of Vilnius city (1919-1927), did express some doubts over the expansion of transport links, construction restrictions and concentrated industrial zones outlined in the plan, saying that its organisers had failed to take the actual conditions and directions of the city's development into proper consideration. ${ }^{37}$

Once Vilnius became incorporated into the Republic of Lithuania (1939), ideas were raised about extending the city's boundaries and joining some surrounding villages and single farmsteads. ${ }^{38}$ These plans were realised. From the description of the Vilnius city boundary, we learn that the city was extended over the whole area's perimeter. Now the eastern part of the city extended as far as the villages of Naujoji Vilnia (Nowa Wilejka), as far as Bukčiai (Buchta I-V) and Lazdynai (Leszczyniaki) to the west, and the villages of Ožkiniai (Oszkińce), Babiniai (Babińce), etc, to the north. ${ }^{39}$

At the time, the city's government prepared a development plan that had much in common with the Polish plan. ${ }^{40}$ The city's zoning (into the Old Town, construction areas, and areas with no construction allowed) and the network of streets was similar to the plans of the Poles. But unlike the Polish plan, the Lithuanian administration saw Vilnius as a centre of importance to the whole state, so the height restrictions for buildings were increased, as was the density of construction, while plot sizes were reduced. According to Jūratė Markevičiené, 'in keeping with the Polish rules, Vilnius was to develop as a spacious and very green city with not very high buildings, simply "merging" into the natural surroundings along its fringes, among the forests, hills and river valleys. Lithuania's capital was to take on more features of a large city, to become more compact and separate from its natural surroundings. ${ }^{41}$ The decree of the Vilnius

36 Decision from the Vilnius voivode dated 4 February 1938, ibid., f. 130, ap. 1, b. $13222,1.7-7 \mathrm{v}$.

37 W. Bańkowski, Wilno przyszłości, p. 27.

38 Copy of the note from K. Alminas, editor of the Republic of Lithuania Ministry of Education Smetona Lithuanian Studies Institute Land Name Directory, dated 29 April 1940, LCVA, f. 415, ap. 4, b. 262, 1. 127-129.

${ }^{39}$ Description of the boundaries of the city of Vilnius (1940), ibid., b. 24, 1. 1-2.

40 J. Markevičienè, 'Nuo šiuolaikinio miesto iki sostinès: urbanistinio Vilniaus ịvaizdžio kaita 1936-1939 m. ir 1939-1940 m.', pp. 107-108.

41 Ibid., p. 108. 
burgomaster Konstantinas Stašys on the development of Vilnius was passed in early June, 1940. The Soviet occupation soon afterwards put an end to its implementation. The long-term plans for the city's development set out by the Poles and the Lithuanians were left in the hands of the Soviet government.

\section{Ethnic demographic distribution in the city}

In a demographic sense, Vilnius had grown rather slowly by the middle of the 19th century. Its population only started to increase rapidly in the second half of the century, a process that continued until the First World War. The demographic changes are reflected in the table below.

Table No. 1. Dynamics of the city population of Vilnius in the 19th and the first half of the 20th centuries

\begin{tabular}{|c|c|}
\hline Year & Population \\
\hline 1859 & $\sim 59,000$ \\
1897 & $\sim 155,000$ \\
1913 & $\sim 240,000$ \\
1920 & $\sim 129,000$ \\
1928 & $\sim 176,000$ \\
1931 & 195,000 \\
1939 & $\sim 195,000$ \\
\hline
\end{tabular}

Table sources: Первая всеобщая перепись населенія Россійской имперіи, 1897 г. IV. Виленская губернія, t. 1, (1900), p. 1; Results of the mechanical movement of the population of Vilnius as of 1 January 1928, LCVA, f. 51, ap. 11, b. 200, p. 86; I. Janicka, Kultura higieniczna, p. 186; V. Stravinskienè, 'Ethnic-demographic changes in the data of the statistical sources of the city of Vilnius (1920-1939)', Lithuanian Historical Studies, vol. 17 (2012), p. 132.

The table shows that during the period under analysis, the population did not reach the figure that had existed prior to the First World War. Compared to other cities in Poland, it was not as appealing to migrants as Warsaw or Łódź. This was because of the city's economic potential. It lay on the country's frontier, and its industrial sector, which paid higher salaries, was poorly developed (becoming even weaker due to the world economic crisis). In this sense, Vilnius lagged behind Poland's other cities. When intensive industrial development commenced in Łódź, in the space of ten years (1921-1931), around 100,000 new arrivals settled there from other areas of Poland, 
and the city had a population of over $600,000 .{ }^{42}$ It should be noted, however, that even though Vilnius and Lviv were the largest cities on Poland's eastern frontier, they were known more for being centres of science and culture, rather than as economic centres.

Police and statistical districts allow for the reconstruction of the distribution of residents in the city. Vilnius was divided into six police and later 11 statistical districts. The surviving documents indicate that Police District I covered the Old Town, Police District II covered the south and southeast parts of the city (from Burbiškees [Burkiszki] to Pučkoriai [Puszkarnia], Police District III covered Žvèrynas and part of Naujamiestis, Police District IV covered the west and northwest parts of the city (from Saltoniškès, Šnipiškès as far as today's Santariškès (Zgoda)), Police District V covered part of Naujamiestis, Vilkpède as far as Žemieji Paneriai, and Police District VI covered the east and northeast parts of the city (from Belmontas to Jeruzale) ${ }^{43}$ The first district had the highest population density, with around 36,000 residents. Somewhat fewer lived in the fourth, third and second districts (from 34,000 to 28,000). The city's east and northeast parts had the smallest populations (around 20,000). In total, at the time the city had a population of $173,730 .{ }^{44}$

The later division of the city into statistical districts and the number of residents in each is shown in Table No. 2.

Table No. 2. The population of Vilnius based on statistical districts in the 1930s

\begin{tabular}{|c|c|c|c|c|}
\hline No. & Statistical district & 1931 & 1936 & 1939 \\
\hline 1 & Senamiestis, Naujamiestis & 41,579 & 39,145 & 40,713 \\
\hline 2 & Naujamiestis, Senamiestis & 35,995 & 33,007 & 35,136 \\
\hline 3 & $\begin{array}{l}\text { Naujininkai, Kaminai, Liepkalnis, Du- } \\
\text { nojus }\end{array}$ & 28,646 & 28,217 & 28,421 \\
\hline 4 & $\begin{array}{l}\text { Rasos, Paplauja, Pavilnis, Markučiai, } \\
\text { Ribiškès, Kuprijoniškès }\end{array}$ & 2,477 & 3,807 & 2,437 \\
\hline 5 & Šnipiškès, Eiguva, Žvejai, Tuskulènai & 25,667 & 27,206 & 25,448 \\
\hline
\end{tabular}

42 Prace statystyczne zarzadu miejskiego w Łodzi 1918-1934 (Łódź, 1937), pp. 25-26.

${ }^{43}$ Registration of the population of the city of Vilnius according to police commissariat boundaries, 1927, LCVA, f. 64, ap. 20, b. 761, 1. unnumbered; Plan of greater Vilnius, Rocznik statystyczny Wilna 1931 (Wilno 1933), insert.

${ }^{44}$ Registration of the population of the city of Vilnius according to police commissariat boundaries, 1927, LCVA, f. 64, ap. 20, b. 761, 1. unnumbered. 


\begin{tabular}{|c|l|c|c|c|}
\hline No. & \multicolumn{1}{|c|}{ Statistical district } & $\mathbf{1 9 3 1}$ & $\mathbf{1 9 3 6}$ & $\mathbf{1 9 3 9}$ \\
\hline 6 & Baltupiai, Jeruzalė, Trinapolis, Santariš- & 1,079 & 1,358 & 1,074 \\
& kès (Zgoda) & & & \\
7 & Žvèrynas, Saltoniškès & 9,990 & 10,648 & 9,722 \\
8 & Antakalnis, Pospieška, Valakampiai & 8,685 & 10,391 & 8,427 \\
9 & Užupis, Belmontas, Pučkorys & 14,180 & 12,488 & 13,907 \\
10 & Naujamiestis & 25,464 & 27,987 & 25,269 \\
11 & Burbiškès, Vilkpèdė, Riovonys, Žemieji & 3,088 & 2,988 & 4,543 \\
& Paneriai & & & \\
\hline & Total & $\mathbf{1 9 6 , 0 5 0 *}$ & $\mathbf{1 9 7 , 2 4 2}$ & $\mathbf{1 9 5 , 0 9 7}$ \\
\hline
\end{tabular}

* Includes temporary residents; there were 193,337 permanent residents.

Table sources: Population of Vilnius city according to the census of 9 December 1931, LCVA, f. 64, ap. 20, b. 920, 1. unnumbered; Rocznik statystyczny Wilna 1935, pp. 238-263; statistical data about the population of Vilnius based on gender, age, religion, language and literacy [1939], LCVA, f. 64, ap. 20, b. 986-990.

The table shows that the population of Vilnius remained rather stable in the 1930s, hardly changing at all. But note that the figures shown here are only approximate. The staff from the Vilnius City Magistrate's Department of Statistics who recorded the city's demographic data did not really know the actual number of residents, and relied only on theoretical calculations. In addition, we should recall that only natural population growth was included in the calculation of the population from 1934 (from 1935 to the first half of 1939, it was around 1,700), as the impact of mechanical population growth (migration) on the city's demography was not considered. ${ }^{45}$ This explains why the total population figure remained almost unchanged.

In the interwar years, more than ten ethnic groups lived in Vilnius. Some consisted of several dozen people, others had tens of thousands. Poles and Jews made up the dominant groups, in terms of numbers, plus there were also relatively large Russian, Lithuanian and Belarusian communities, and smaller groups of Tatars, Karaites, Germans and Latvians. According to official data, at the end of the period under review, there were around 130,000 Poles in Vilnius, around 54,000 Jews, 1,500 Lithuanians and Belarusians each, over 7,000 Russians, 300 Tatars, 200 Karaites, and a few hundred members of other ethnic groups. ${ }^{46}$ But in

${ }^{45}$ Note dated 9 February 1939 from W. Pac-Pomarnacki, serving as head of the Central Statistical Bureau, to the Supreme Statistical Board in Warsaw, LCVA, f. 64 , ap. 20 , b. $963,1.3$.

${ }^{46}$ Statistical data about the population of Vilnius based on gender, age, religion, language and literacy (1939), ibid., b. 986-990. 
fact, Polish nationals did not make up the largest group. Jewish authors have calculated that during the interwar years, there were around 60,000 Vilnius Jews. ${ }^{47}$ Similar results were stated for residents of other nationalities. It has been calculated that the number of Lithuanians in Vilnius was 5,000 to 6,000 , and there were 12,000 to 13,000 Russians. ${ }^{48}$ But these figures do not really change the city's ethnic structure. In those days, Vilnius was primarily a Polish-Jewish city.

In the $1930 \mathrm{~s}$, the majority of residents $(80 \%$, or around 144,000 people) lived in the Senamiestis, Naujamiestis, Naujininkai and Šnipiškès-Eiguva areas. Jews undoubtedly dominated in the first, where they numbered 27,000, with Poles making up 12,000. ${ }^{49}$ This kind of situation was not an exception. As in Vilnius, Jews made up a majority of the populations of cities elsewhere in Lithuania and Poland. In Kaunas, $27 \%$ were Jews, in Panevėžys 36\%, in Warsaw 28\%, in Łódź $31 \%$, and in Krakow $21 \% .{ }^{50}$ They were concentrated in city centres, for example, in the Old Town of Łódź, Jews made up around 57\% of the population. ${ }^{51}$

A relatively large number of Jews lived in the Naujamiestis in Vilnius too, where they made up around a third of the area's residents, but this area was dominated by Poles. The Šnipiškiès-Eiguva suburb was also home to many Jews (there were over 25,000 residents in the area, of whom 4,000 were Jews). ${ }^{52}$

${ }^{47}$ S. Atamukas, Lietuvos žydu kelias (Vilnius, 2007), p. 178; Lietuvos tautinès mažumos. Kultūros paveldas (Vilnius, 2001), p. 44.

48 B. Makauskas, Vilnijos lietuviai 1920-1939 metais (Vilnius, 1991), p. 21; P. Bieliauskas, Dienoraštis 1920-1957 (Vilnius, 2012), p. 346; number of Orthodox churches and Orthodox believers in Vilnius, 1 July 1925, LCVA, f. 53, ap. 23, b. 725, 1. 370; data about religion and sects in the Vilnius district, 6 October 1924, ibid., f. 51 , ap. 15 , b. 217 , 1. 5 .

49 Data on native language from the census of 9 December 1931, ibid., f. 64, ap. 20 , b. 920 , 1. 240.

${ }^{50}$ Lietuvos gyventojai: pirmojo, p. XXXVIII; Drugi powszechny spis ludności $z$ dn. 9. XII. 1931 r: Mieszkania i gospodarstwa domowe. Ludność. Stosunki zawodowe: Miasto St. Warszawa, p. 18; Drugi powszechny spis ludności z dn. 9. XII. 1931 r: Mieszkania i gospodarstwa domowe. Ludność. Stosunki zawodowe: Miasto Łódź, p. 14; Drugi powszechny spis ludności z dn. 9. XII. 1931 r: Mieszkania i gospodarstwa domowe. Ludność. Stosunki zawodowe: Miasto Kraków, p. 11.

${ }^{51}$ Prace statystyczne zarzadu miejskiego $w$ Lodzi 1918-1934, p. 26; Drugi powszechny spis ludności z dn. 9. XII. 1931 r: Mieszkania i gospodarstwa domowe. Ludność. Stosunki zawodowe: Miasto Łódź, p. 16.

52 Statistical data about the population of Vilnius based on gender, age, religion, language and literacy (1939), LCVA, f. 64, ap. 20, b. 985, 1. 242-278; b. 990, 1. 140-170. 
People from other ethnic groups also had 'their own' suburbs. Russians usually concentrated in Naujininkai, Rasos, Liepkalnis and Kaminai, Lithuanians and Belarusians in the city centre, Germans lived mostly in the Senamiestis and Užupis, Karaites lived in the centre and the Žverynas and Saltoniškès suburbs, while Tatars lived in Šnipiškès, Rasos and Liepkalnis.

The art researcher Laima Laučkaite has noted that each suburb of Vilnius had its own distinct character: the archaic intersecting streets of Užupis and Antakalnis, lined with wooden houses, and the small manor houses scattered up the slopes towards the ridge, the neat and spacious Žverynas, the plebeian and chaotic overcrowding of Šnipiškės, the outlying Vilkpėde, home to railway workers, Pavilnys, with its wonderful views, Paplauja and Markučiai, reminiscent of Switzerland, and the villas hidden among the forests of Valakupiai and Leoniškès. ${ }^{53}$ The suburbs truly had a number of specific characteristics, including social and demographic ones. The city's main suburb (Senamiestis) exhibited a degree of contrasts. In a social sense, this area was home to people who enjoyed a more stable situation (being materially wealthier), such as merchants and traders. Apartments of three to four rooms dominated. However, beside them, smallscale traders and artisans struggled to get by, like the skudurininkai (rag-people), who lived in poverty and crowded into one-room apartments. ${ }^{54}$ Although the area was in the very centre of the city, its high population density and lack of proper sewerage meant some sections gave the impression of being run-down and dirty.

The area lying to the west of the Senamiestis could be termed as the 'state offices suburb', where financial, trading, justice and other specialised institutions were concentrated (banks, commercial and legal chambers, hotels). ${ }^{55}$ The population here was wealthier, and belonged to the intelligentsia and higher-ranking civil servants (lawyers, doctors, large property owners). They lived in large, comfortable apartments. In the central part of the city, apartments of six to ten rooms dominated, ${ }^{56}$ and many of the buildings were made of brick.

${ }^{53}$ L. Laučkaite, 'Užmirštas medinis Vilnius', 7 meno dienos, 20 October 2006, No. 727, http://eia.libis.lt:8080/archyvas/viesas/20110307030528/http://www.culture. 1t/7md/?leid_id=727 (accessed 5-2-2016).

${ }^{54}$ Description of Police District I in Vilnius (1939), LCVA, f. 64, ap. 20, b. $980,1.258$.

55 W. Bańkowski, Wilno przyszłości, p. 10.

${ }^{56}$ Description of Police District III in Vilnius (1939), LCVA, f. 64, ap. 20, b. $980,1.256$. 
In interwar Vilnius, just $28 \%$ of the buildings were brick (in total, there were around 12,000 residential buildings). ${ }^{57}$ Most of the suburbs were 'wooden', for example, in Žvèrynas in 1938, only $20 \%$ of the buildings were built of brick. ${ }^{58}$

The city's working classes concentrated on the eastern (mostly railway workers) and southern edges of the city, while artisans and lower-ranking civil servants lived in the Šnipiškès and Saltoniškees suburbs. In these areas, there were mostly one to three-room apartments in wooden buildings. ${ }^{59}$ But unlike the population of the city centre, the residents of these areas were younger, as a lot of children lived there. ${ }^{60}$ Further away from the city centre, towards the fringes, living conditions worsened. In 1932, there were around 40,000 homes in Vilnius with one or more rooms, of which $39 \%$ had electricity $(68,500$ people had access to electricity), $15 \%$ had running water (26,500 people had access to the water supply network), and a sewerage system was found in $15 \%$ of homes $\left(26,500\right.$ people). ${ }^{61}$ Residents of the fourth and 11th statistical districts (Rasos, Paplauja, Pavilnis, Markučiai, Vilkpėde, Riovonys, etc) had the fewest modern conveniences.

\section{Conclusions}

Three periods stand out in the development of the city of Vilnius: 1) 1916-1918, the years of the German occupation, when the area of the city saw extensive growth; 2) 1919-1939, the 'Polish' stage, during which territorial expansion was rather insignificant (the city's area increased by around 600 hectares); and 3) 1939-1940, when the city's expansion was carried out by institutions of the Republic of Lithuania to the detriment of surrounding areas.

Starting in 1916, the 'greater' Vilnius plan was implemented during the course of the entire period under analysis. The plan that began with the German government was approved and continued by Polish and Lithuanian institutions. During this time, the city extended most-

${ }^{57}$ Rocznik statystyczny Wilna 1931, p. 7.

58 J. Szałygin, 'Zabytkowa drewniana architektura mieszkalna wileńskiego Zwierzyńca', p. 216, http://www.nid.pl/upload/iblock/4e2/4e2c241de440880bdf9040 60a56b9894.pdf (accessed 6-2-2016).

${ }^{59}$ Description of Police Districts II and III in Vilnius (1939), LCVA, f. 64, ap. 20, b. 980, 1. 256-256v.

${ }^{60}$ A. Merelin, Przyczynek do, p. 2.
${ }^{61}$ Rocznik statystyczny Wilna 1935, pp. 262-263. 
ly towards the west and south, into areas where industrial development was planned.

The demographic situation in the city changed slowly due to the First World War and its outcome, the tensions in Lithuanian-Polish relations, and Poland's economic situation. During the period under review, the number of residents in Vilnius did not reach the figure that existed prior to the First World War (195,000 in 1939, and 240,000 in 1913). Even though Vilnius was very spread out, residents were generally concentrated in four suburbs (Senamiestis, Naujamiestis, Naujininkai and Šnipiškès-Eiguva), that is, in 'little' Vilnius.

The populations of Vilnius had 'their own' areas, based on ethnicity. Jews concentrated mostly in Senamiestis and Naujamiestis, Russians lived mostly in the suburbs of Naujininkai, Rasos and Liepkalnis, Lithuanians and Belarusians lived in the city centre, Germans preferred the centre and Užupis, the Karaites chose the centre, Žvèrynas and Saltoniškès, while the Tatars lived in Šnipiškès, Rasos and Liepkalnis.

In a social sense, the city's elite and intelligentsia dominated in the central part of the city. However, in the case of the Senamiestis, alongside socially stable members of the population, there were also materially poorer families (Jews). People from the lower social classes (labourers and artisans) lived mostly in suburbs further away from the city centre, in smaller apartments without modern conveniences. It should be noted that towards the end of the period of analysis, only around a quarter of the city's population had running water and a sewerage system in their homes, and only a little over half had electricity.

\section{Author Details}

Vitalija Stravinskiene is a research fellow in the Department of 20th Century History at the Lithuanian Institute of History. Her area of research is Vilnius and east and southeast Lithuania in the 20th century.

Address: Lithuanian Institute of History, Kražių g. 5, Vilnius LT-01108

E-mail: vitalija.stravinskiene@istorija.lt 


\section{References}

ATAMUKAS, S. Lietuvos žydų kelias (Vilnius, 2007).

ANTANAVIČIŪTĖ, R. 'Viešosios Vilniaus erdvès tarpukariu: Antrosios Žečpospolitos didmiesčio konstravimas', Sostine kaip tapatumo simbolis. Vilnius ir Kaunas tarpukario kultūroje, eds. A. Lapinskienè, V. Šeina (Vilnius, 2014).

ANTANAVIČIŪTĖ, R. Politinès galios simboliai Vilniaus viešojoje erdveje 1895-1953 metais. Doctoral dissertation (Vilnius, 2015).

BALIŃSKI, M. Opisanie statystyczne miasta Wilna (Wilno, 1835).

BAŃKOWSKI, W. Wilno przysztości. Rozważania na tematy urbanistyczne (Wilno, 1937).

BAUŽIENĖ, M. Pasižvalgymas anapus Vilniaus miesto gynybinès sienos (Vilnius, 2015).

BAUŽIENĖ, M. Pasižvalgymas po senojo Vilniaus mūrus (Vilnius, 2012).

BIELIAUSKAS, P. DienoRaštis 1920-1957 (Vilnius, 2012).

ČAPLINSKAS, R.A. Vilniaus gatvès. Istorija, vardynas, žemèlapiai (Vilnius, 2010).

ČAPLINSKAS, R.A. Vilniaus istorija: legendos ir tikrove (Vilnius, 2010).

ČAPLINSKAS, R.A. Šv. Jono, Dominikonu, Traku gatves (Vilnius, 1998).

DIJOKIENĖ, D. 'Vilniaus istorinių priemiesčiu genezès, raidos ir vertybių ypatumai', Urbanistika ir architektūra, 2 (2006).

DRĖMA, V. Vilniaus namai archyvu fonduose (Vilnius, 1998).

DRĖMA, V. Dingęs Vilnius (Vilnius, 1991).

GIRININKIENE, V. Vilniaus Bernardinu kapinès (Vilnius, 2010).

JACKIEWICZ, M. Wilno w XX wieku. Ludzie i wydarzenia (Bydgoszcz, 2013).

JANICKA, I. Kultura higieniczna Wilna w latach 1795-1915 (Gdańsk, 2009).

JANUŠAUSKAITĖ, V. 'Lazdynai - sukonstruota vietos dvasia?', Vietos dvasios beieškant, ed. R. Čepaitienè (Vilnius, 2014).

JUREVIČIENĖ, J. 'Vilniaus istoriniai priemiesčiai: autentiškumo aspektas', doctoral dissertation (Vilnius, 2005).

JUREVIČIENĖ, J. 'Medinè architektūra istoriniame priemiestyje. Vilniaus Užupio autentiškumas', Urbanistika ir architektūra, 1 (2002).

KASPERAVIČIENE, A., SURWIŁO, J. Przechadzki po Wilnie. Zarzecze. Cmentarz Bernardyński (Wilno, 1997).

KLIMAŠAUSKIENĖ, T. Pavilnys, 1908-2008: Wileńska Kolonja Kolejowa (Vilnius, 2008).

KORZENIEWSKI, B. 'Polityka ekonomiczna władz niemieckich okupacyjnych w czasie pierwszej wojny światowej i strategia przetrwania mieszkańców południowego Podlasia', Radzynski Rocznik Humanistyczny, 5 (2007), http://www.rasil.home.pl/rrh_5_2007/04_boguslaw_korzeniewski. pdf (accessed 20-14-2016). 
LAUČKAITĖ, L. 'Užmirštas medinis Vilnius', 7 meno dienos, 727 (2006).

Lietuvos tautinès mažumos. Kultūros paveldas (Vilnius, 2001).

LISAUSKAS, V. Vilnius: Užupis ir gretimos erdvès (Vilnius, 2002).

MAKAUSKAS, B. Vilnijos lietuviai 1920-1939 metais (Vilnius, 1991).

MARKEVIČIENĖ, J. 'Nuo šiuolaikinio miesto iki sostinès: urbanistinio Vilniaus įvaizdžio kaita 1936-1939 m. ir 1939-1940 m.’, Sostiné kaip tapatumo simbolis. Vilnius ir Kaunas tarpukario kultūroje, eds. A. Lapinskienè, V. Šeina (Vilnius, 2014).

MEILUS, E., JOGÉLA, V., PUGAČIAUSKAS, V. Lukiškès: nuo priemiesčio iki centro (XV a. $-X X$ a. pradžia) (Vilnius, 2008).

MEZELIN, A. Przyczynek do znajomości struktury wiekowej Wilna (Kraków, 1936).

Pasižvalgymai po Vilnių: miesto mikrorajonai (Vilnius, 2015).

POCEVIČIUS, D. 100 istoriniu Vilniaus reliktu (Kaunas, 2016).

PTAŠEK, M. 'Žvèryno užstatymas ir pastatų stilistinè charakteristika', Vilniaus Technikos Universiteto mokslo darbai. Urbanistika ir rajony planavimas, 18 (1993).

RACEVIČIENĖ, A. Teritorija tarp Maironio, Aukštaičiu, Paupio, Zarasu ir Polocko gatviu. Istorinès urbanistinés raidos analizè (Vilnius, 2006).

RICHTER, A. 'Bezrobotny proletariat w Wilnie', Wilno, 2 (1939).

RYLIŠKIS, R. Markučiai: Vilnios slènis (Vilnius, 2010).

RYMKEVIČIŪTĖ, A. 'Medinis Vilniaus paveldas: Žvėryno medinès architektūros vertès', http://www.bernardinai.lt/straipsnis/-/3693 (accessed 10-2-2016).

ROSIAK, S. Wileńska Kolonja Kolejowa, 1908-1933 (Wilno, 1933).

SNOPKO, J. 'Rządy niemieckie w Grodnie i okolicy (1915-1917)', Studia Podlaskie, XXII (2014).

STRAVINSKIENE, V. 'Ethnic-Demographic Changes in the Data of the Statistical Sources of the City of Vilnius (1920-1939)', Lithuanian Historical Studies, 17 (2012).

SURVILO, J. Pamiętam Antokol : przechadzki po Wilnie (Vilnius, 2005).

SZAŁYGIN, J. 'Zabytkowa drewniana architektura mieszkalna wileńskiego Zwierzyńca’, Ochrona Zabytków, 1-4 (2010).

ŠIAUDINIS, V. Vilniaus maldos namai (Vilnius, 2001).

VANAGAS, J. Primirštas Antakalnis (Vilnius, 2015).

VENCLOVA, T. Vilniaus vardai (Vilnius, 2006).

Vilnius: 100 memorable sites of Jewish history and culture (Vilnius, 2006).

VITKUS, A. Verkiai. Istorija ir dabartis (Vilnius, 2009). 


\title{
VILNIAUS MIESTO TERITORINĖ PLÉTRA: PLANAI IR JŲ REALIZAVIMAS (1916-1940)
}

Santrauka

\author{
VITALIJA STRAVINSKIENE்
}

Straipsnyje nagrinejami Vilniaus miesto teritorijos plètros planai ir jų igyvendinimas 1916-1940 m. („didžiojo“ Vilniaus kūrimas), to meto miesto etninè demografinè sudetis ir jos dinamika. Autorè skiria tris miesto geografinès raidos etapus: 1) pirmojo pasaulinio karo metus (1916 m.), kai Vilniaus miesto teritorija buvo padidinta beveik du kartus (miesto plotas sudare apie 10 tūkst. kvadratinių kilometrų); 2) 1919-1939 m. - Lenkijos valdžios institucijų vykdytas Vilniaus ribų plètimas (miesto plotas apėmé 10400 ha), tikslinimas, ilgalaikių plètros planų rengimas; 3) 1939-1940 m. - Lietuvos Respublikos institucijų vykdoma tolesnè miesto teritorijos plètra.

Nagrinejjamu laikotarpiu Vilniaus mieste daugiausiai gyveno lenkų ir žydų (1939 m. pirmieji sudare apie 66 proc., antrieji - apie 29 proc. visu miestiečių). Dar mieste gyveno daugiau kaip dešimties etninių grupių atstovai.

Nors Vilnius teritoriniu požiūriu buvo labai išsiplètęs, gyventojai iš esmès telkèsi keturiuose rajonuose (Senamiesčio, Naujamiesčio, Naujininkų ir ŠnipiškiųEiguvos), t. y. vadinamajame „mažajame“ Vilniuje. Etniniu požiūriu Vilniaus miesto gyventojai turèjo „savo“ gyvenamus rajonus. Žydai daugiausia telkèsi Senamiestyje, rusai - Naujininkų, Rasų, Liepkalnio rajone, lietuviai, baltarusiai - miesto centre, vokiečiai - centre ir Užupyje, karaimai - centre ir Žvèryne bei Saltoniškèse, totoriai - Šnipiškių, Rasų ir Liepkalnio rajonuose.

Miesto centrineje dalyje dominavo elitas, inteligentija. Senamiestyje greta pasiturinčių asmenų gyveno neturtingi (žydai). Žemesnių socialinių sluoksnių atstovai (darbininkai, amatininkai) gyveno labiau nuo centrinès miesto dalies nutolusiuose rajonuose, ankštuose, buitinių patogumų neturinčiuose butuose. Apskritai reikia pasakyti, kad XX a. 4-ojo dešimtmečio antroje pusejje tik maždaug ketvirtadalis miesto gyventojų turẻjo vandentiekị ir kanalizaciją, kiek daugiau nei pusė naudojosi elektros energija. 